Article

\title{
Study of Power Quality at the Point of Common Coupling of a Low Voltage Grid and a Distributed Generation System of $7.8 \mathrm{kWp}$ in a Tropical Region
}

\author{
Agustín Valverde Granja ${ }^{1}$ (D), Teófilo Miguel de Souza ${ }^{2}$, Pedro Magalhães Sobrinho ${ }^{2}$ \\ and Daniel Felipe Arévalo Santos ${ }^{1, *}$ \\ 1 Facultad de Ingeniería, Universidad de Ibagué, Ibagué 730001, Colombia; \\ agustin.valverde@unibague.edu.co \\ 2 School of Engineering, Universidade Estadual Paulista (UNESP) Câmpus Guaratinguetá, \\ Guaratinguetá 01049-010, Brazil; teofilo@feg.unesp.br (T.M.d.S.); sobrinho@feg.unesp.br (P.M.S.) \\ * Correspondence: 2120111009@estudiantesunibague.edu.co; Tel.: +57-316-419-3689
}

Received: 25 May 2018; Accepted: 7 June 2018; Published: 13 June 2018

\begin{abstract}
In this paper we analyze an experimental $1000 \mathrm{kWh} / \mathrm{month}$ distributed generation system in a tropical region connected to a point of common coupling in a low voltage grid that was characterized according to NTC 5001. This photovoltaic system has $7.8 \mathrm{kWp}$ and uses 30 polycrystalline silicon-panels of $260 \mathrm{Wp}$ each. Its maximum energy produced was $850 \mathrm{kWh} / \mathrm{month}$, equivalent to $72.65 \%$ of the installed capacity. Finally, there was an increase of $2 \%$ with respect to the minimum voltage value that was recorded. The voltage unbalance decreases between 3.5 and $70 \%$ and voltage harmonics in each line increased by $7 \%$ on line $\mathrm{U} 1,0.8 \%$ on $\mathrm{U} 2,3 \%$ on U3 and current harmonics have a $22 \%$ increase. Likewise, the total active and reactive power were increased by $58 \%$ and $42 \%$ respectively, and the thermography study allowed to establish a temperature increase at the point of common coupling of $7.5 \%$. Therefore, it is expected that this paper can serve as a reference for the application of Colombian law 1715 in solar energy.
\end{abstract}

Keywords: solar energy; experimental network; power quality; low voltage

\section{Introduction}

In response to the increase in energy demand and environmental restrictions on greenhouse gas emissions around the world, attention is now focused on renewable energy sources. Solar energy is considered an unlimited resource, so it could contribute to reduce the use of fossil fuels and their negative impacts. Moreover, it is considered more environmentally-friendly [1], safer, noise-free and easy to install [2]. Photovoltaic systems (PV) are manufactured using semiconductor materials such as silicon, which converts the incident radiation into electricity. This process is carried out directly and instantaneously, without complicated mechanical components [3] with maximum efficiencies reached in the range of $12-15 \%$ [4], in the case of commercial polycrystalline silicon cells.

Likewise, the PV industry and the market have grown rapidly in recent years, the main reason being the reduction of the generation costs and government policies that promote the introduction of PV systems connected to the grid. However, this growth has not been followed by developments in the field of failure diagnosis, monitoring and detection in PV systems, particularly in power outputs smaller than $25 \mathrm{kWp}$ [5], a procedure that allows one to establish the state of a PV installation, the efficiency with which it is operating, as well as its behavior against climatic variables, such as ambient temperature, solar radiation and wind speed.

The International Energy Outlook (IE) indicates that energy consumption will increase by more than $28 \%$ in $2015\left(6.06 \times 10^{26} \mathrm{~kJ}\right)$ to $2040\left(7.76 \times 10^{26} \mathrm{~kJ}\right)$ and predicts that there will be a significant 
increase in the consumption of coal reserves in the next 20 years. This institution suggests that, in order to achieve a contribution to global energy demand and a significant impact on pollution reduction, renewable energy sources should grow in such a way that, by the year 2050 they will become more than half of the world's energy needs [6]. According to the Renewable Energy police Network for the 21st Century (REN21), the contribution of renewable energy to global energy generation is $16 \%$. The so-called new renewable energies, which include photovoltaic generation, contribute $0.6 \%$ [7].

It must be added that interconnected photovoltaic systems are being used as a complement to conventional energy generation in many countries [8,9]. Applications range from a small power generation in remote areas in the past 25 years to the installation of centralized stations with large photovoltaic generation capacity scale. In recent years, a great interest in urban consumers has been generated as a distributed generation application, where plants with small generation capacity are installed on the roofs of buildings or residences within the Building Integrated Photovoltaic Systems (BIPVS) concept. Nowadays, there is a variety of hybrid energy solutions for building applications [10-13], and especially ones with the integration of photovoltaics [14-16]. Their implementation mostly depends on the climate, geographical location, building type and on the availability of the energy resources on site. Despite the promising potential, one of the most important problems of PV systems is the dimensioning of its components, because, if a PV system is not correctly dimensioned, it does not work as expected [17].

Therefore, the sizing of grid-connected photovoltaic systems (GCPV) involves two main procedures, namely the technical sizing procedure and the economic sizing to determine the expected technical performance indicators and the economic performance indicator of the proposed system. In technical terms, the estimation of the energy produced by a GCPV is a widely studied concept [18-21]; we can find, based on various approaches to design-based software recently introduced, [22] methods and models for simulation to simplified calculation methods [23,24].

Currently there are online calculation methods that web pages of different organisms display, such as Joint Research Center (JRC) [25]. The design of the photovoltaic system connected to the low voltage grid (GCPV) of $7.8 \mathrm{kWp}$ in this case of study was carried out following the recommendations by [26-28] with regard to the system evaluation, studies have been carried out in Europe and worldwide on the performance of photovoltaic systems operating outdoors as reported by [29-35].

On the behavior of the power quality at the point of common coupling (the low voltage network and a distributed generation system), many authors propose some possible solutions. Marnay [36], proposed a control strategy to control the voltage imbalance, the total harmonic distortion and the voltage gaps or SAGS, caused by large non-linear and unbalanced loads. Li et al. [37], suggested the use of a series-parallel converter to control the voltage imbalance and the current demand in the case of a fault in the network. A converter consisting of three single-phase inverters to control unbalanced and non-linear loads is proposed by [38,39]. Papadimitriou et al. [40] suggest that the imbalance of power, during the transition of the micro-grid from the mode connected to the disconnected can be restricted with a fuzzy and Zamani control et al. [41] proposed a closed-loop control strategy that allows the micro-grid to maintain a good power quality without changing the modes.

Although Latin America has a high potential for the use of photovoltaic energies [42], it lacks such studies. The performance evaluation of photovoltaic systems involves the calculation of the following parameters: annual energy generation, reference performance, final yield, system losses, loss of cell temperature, photovoltaic module efficiency, capacity factor and yield ratio among others [32]. The results obtained provided useful information to policymakers and organizations interested in the actual performance of grid-connected photovoltaic systems in a region or country [43].

Colombia has abundant natural resources, including a high-water potential, gas, coal, wind resources, solar energy and biomass. It is also located in an area of high geological activity that would make geothermal exploitation possible. One of the main difficulties is the lack of detailed information on the true potential of non-conventional renewable energy sources. 
In general, the whole territory of Colombia has a good solar energy potential, with a daily average insolation of around $4.5 \mathrm{kWh} / \mathrm{m}^{2}$ (La Guajira Peninsula, with an average value of $2.200 \mathrm{kWh} / \mathrm{m}^{2} /$ year can be highlighted) (Figure 1). Although Colombia has favorable legislation for alternative energies, the costs of implementation of photovoltaic systems compared to other energy sources remain high, with current costs of $2100 \mathrm{USD} / \mathrm{kWp}$, only exceeded by geothermal generation at $2200 \mathrm{USD} / \mathrm{kWp}$ and higher than hydroelectric power plants with costs of $1300 \mathrm{USD} / \mathrm{kWp}$, coal-fired power plants of $800 \mathrm{USD} / \mathrm{kWp}$, thermoelectric plants with combined cycle gas with $900 \mathrm{USD} / \mathrm{kWp}$, wind power plants at $1200 \mathrm{USD} / \mathrm{kWp}$ and cogeneration $500 \mathrm{USD} / \mathrm{kWp}$. However, due to the low operation and maintenance costs of photovoltaic systems, these can surpass coal-fired power plants and combined-cycle gas-fired thermoelectric plants, making them an excellent alternative to be included in the Colombian energy matrix.

In 2014, Colombian government signed law 1715 which established the legal framework for the promotion and exploration of non-conventional energy sources, mainly from renewable sources, the promotion of investments, research and development of clean technologies in energy production. Experimental studies are needed to solve the problems of voltages caused by photovoltaic systems, since experimental data can show the actual behavior of the system.

Thus, all the technical problems (voltage, power, synchronicity, flicker and frequency) originating at the point of common coupling between the grid and the photovoltaic system should be thoroughly studied before its implementation. In this paper an evaluation of a photovoltaic system of $7.8 \mathrm{kWp}$, connected to a point of common coupling of a low-voltage grid, located in the city of Ibagué (Colombia) was carried out. Besides that, in this paper we present the behavior of the power quality at the common point of connection between a distributed generation system and a low voltage grid in a tropical region. This work is organized as follows: Section 2 describes the system and shows the evaluation parameters based on standards for Colombia. Section 3 explains the methodology of Colombian Technical Standard NTC 5001 for measurements in the energy quality studies. Following this, we present the instruments for the measurement in Section 4. Section 5 summarizes our results (system efficiency, power quality and thermography analysis), while Section 6 offers the conclusions.

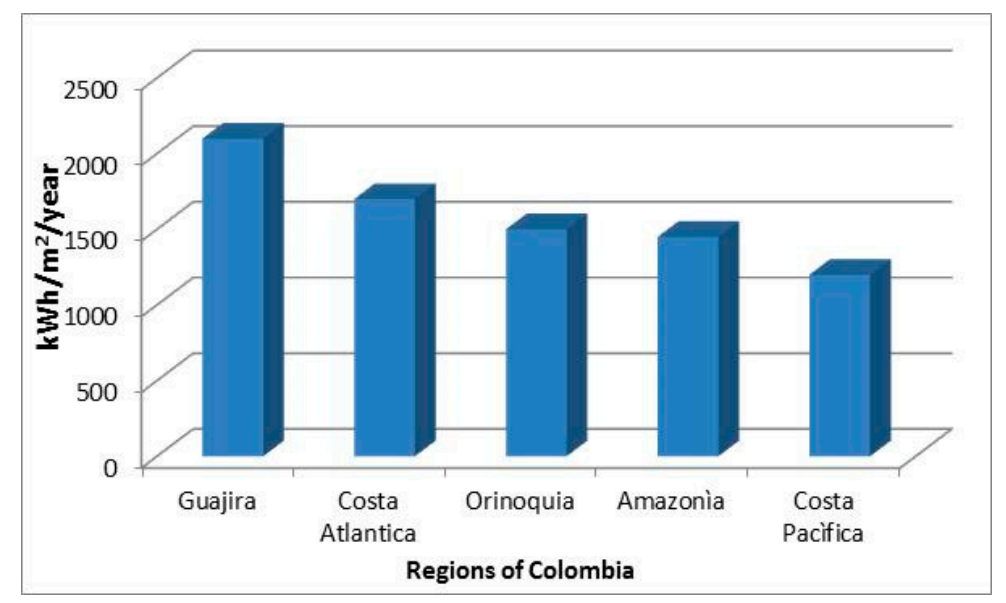

Figure 1. Annual solar radiation for the different strategic regions of Colombia.

\section{Description of the Photovoltaic System Connected to the Low Voltage Grid}

The experimental photovoltaic system has operated from February 2016 to date. It is located in block 3 at the Universidad de Ibagué at 1285 above sea level, latitude $4^{\circ} 26^{\prime} 54^{\prime \prime} \mathrm{N}$, longitude $75^{\circ} 11^{\prime} 56^{\prime \prime} \mathrm{W}$. The structure is made of I-beams of AISI 1045 steel, whose slope was calculated to be $12.3^{\circ}$, as shown in Figure 2, The system consists of 30 panels tilted at a fixed angle of $14^{\circ}$ and oriented towards the north with an azimuth of $4^{\circ}$, it is divided into three modules with 10 IBC PolySol 260-CS polycrystalline silicon panels each (Colombinvest, Bogotá, Colombia, Table 1), which are connected in series covering 
an area of $49.1 \mathrm{~m}^{2}$. A Fronius Primo 7.6-1 inverter (Colombinvest, Bogotá, Colombia, Table 2) with a rated maximum efficiency of $96.9 \%$ and maximum $\mathrm{AC}$ power of $7600 \mathrm{~W}$ is also part of the circuit, as well as the Itron ACE300 bidirectional counter (Colombinvest, Bogotá, Colombia), which measures the data about the total energy generation.

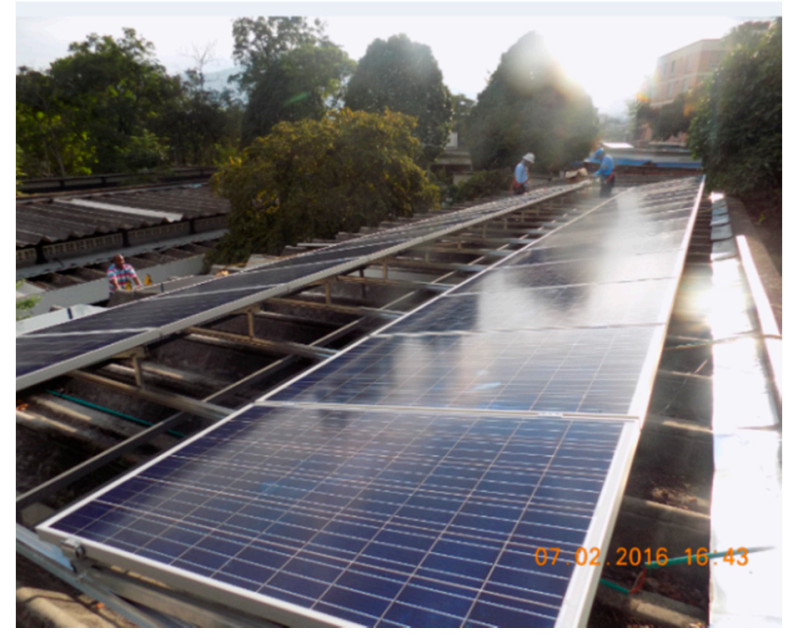

Figure 2. Photovoltaic system used.

Table 1. Technical data IBC PolySol 260 CS.

\begin{tabular}{ccc}
\hline Electrical Data (STC) & Minimum & Maximum \\
\hline STC Power Pmax (Wp) & 260 & 265 \\
STC Nominal Voltage (V) & 311 & 31.4 \\
STC Nominal Current (A) & 8.37 & 8.44 \\
STC Open Circuit Voltage (V) & 38.1 & 38.6 \\
STC Short Circuit Current (A) & 8.98 & 9.03 \\
Module Efficiency (\%) & 15.9 & 16.2 \\
Power Tolerance (Wp) & $-0 /+5$ & $-0 /+5$ \\
\hline
\end{tabular}

Table 2. Fronius Primo 7.6-1 technical data.

\begin{tabular}{lc}
\hline \multicolumn{2}{c}{ Input Data } \\
\hline Number of MPPT & 2.0 \\
Recommended PV Power (kWp) & $6.1-11.7 \mathrm{kWp}$ \\
Max. usable input current & $18.0 / 18.0 \mathrm{~A}$ \\
Max. usable input current total & $36.0 \mathrm{~A}$ \\
Max. array short circuit current & $27 / 27 \mathrm{~A}$ \\
Nominal input voltage & $420.0 \mathrm{~V}$ \\
Operating voltage range & $80-1000 \mathrm{~V}$ \\
\hline \multicolumn{1}{c}{ Output Data } \\
Max. output power 240 V & $7600 \mathrm{VA}$ \\
Max. output power 208 V & $7600 \mathrm{VA}$ \\
Output configuration & NPE 208/204 V \\
Frequency range & $45-66 \mathrm{~Hz}$ \\
Nominal operating frequency & $60.0 \mathrm{~Hz}$ \\
Total harmonic distortion & $<5 \%$ \\
Power factor range & $0.85-1 \mathrm{ind} . / \mathrm{cap}$. \\
Max. Efficiency & $96.9 \%$ \\
\hline
\end{tabular}


Moreover, the sizing ratio, which represents the ratio between the PV array installed capacity and the inverter capacity, in the present case, is 1.0. Data is recorded in $1 \mathrm{~min}$ intervals and processed by a computer. Solar radiation, wind speed and ambient temperature were provided by an automatic Meteorological Station (100 m away from the PV system) at the Universidad de Ibagué, Colombia.

\subsection{Performance Parameters}

In order to evaluate the performance of a photovoltaic system connected to the low voltage grid, parameters of the IEC 61724 standard are taken as a reference: output energy, yields (Reference, Array, Final), array and system losses, Efficiencies (Array, System, Inverter) [29-35]. These standardized performance parameters are relevant because they provide a basis by which grid-connected photovoltaic systems can be compared under various operating conditions [29].

\subsection{System Efficiency}

The yields indicate the actual operation of the modules relative to their rated capacity; they can be classified into three types: array performance $\left(Y_{m}\right)$, final $\left(Y_{F}\right)$ and reference $\left(Y_{R}\right)$ [29]. The array performance $\left(Y_{m}\right)$ is defined as the output direct current $(D C)$ of the photovoltaic array over a period of time, divided by the nominal power. Other authors represent it as the time, measured in $\mathrm{kWh} / \mathrm{kWp}$, that the photovoltaic modules must operate at their nominal power to generate the energy produced [44]. It is represented by Equation (1):

$$
Y_{m}=\frac{E_{D}}{P_{P V}}\left(\frac{\mathrm{kWh}}{\mathrm{kW}}\right)
$$

where $E_{D}$ is the energy output of the photovoltaic module in $(\mathrm{kWh})$, and $P_{P V}$ the nominal power of the array in $\mathrm{kWp}$.

The final yield $\left(Y_{F}\right)$, defined as the total energy $\left(E_{A}\right)$ generated by the PV over a period of time divided by the nominal output power $\left(P_{P V}\right)$ of the installed system [45], is given in Equation (2):

$$
Y_{F}=\frac{E_{A}}{P_{P V}}\left(\frac{\mathrm{kWh}}{\mathrm{kW}}\right)
$$

The reference yield $\left(Y_{R}\right)$ is a measure of the theoretical available energy at a specific location over a period of time, corresponds to the total in-plane irradiance $\left(G_{T}\right)$, divided by the reference irradiance $\left(G_{R}\right)$ under conditions of Standard temperature which is $1 \mathrm{~kW} / \mathrm{m}^{2}$, obtained with Equation (3):

$$
Y_{R}=\frac{G_{T}}{G_{R}}\left(\frac{\mathrm{kWh}}{\mathrm{kW}}\right)
$$

The modules capture losses $\left(L_{m}\right)$ which are the difference between the reference yield $\left(Y_{R}\right)$ and the array performance $\left(Y_{m}\right)$, it represents the losses due to the operation of the modules that demonstrate the inability of the system to fully utilize the available irradiance [46]. They are obtained by Equation (4):

$$
L_{m}=Y_{R}-Y_{m}\left(\frac{\mathrm{kWh}}{\mathrm{kW}_{\mathrm{p}}}\right)
$$

The inverter losses $\left(L_{I}\right)$ due to the conversion from DC power output to AC power in PV solar panels. They are given by Equation (5):

$$
L_{I}=Y_{m}-Y_{F}\left(\frac{\mathrm{kWh}}{\mathrm{kW}}\right)
$$

The efficiency of a PV system can be grouped into three categories: the photovoltaic module efficiency, system efficiency and inverter efficiency. The photovoltaic module efficiency $\left(\eta_{P V}\right)$, is the 
relationship between the daily output power $\left(E_{D}\right)$ and the total daily irradiation product in the $\left(G_{T}\right)$ plane and the area of the photovoltaic array $\left(A_{m}\right)$ [46]. PV module efficiency is calculated by the Equation (6):

$$
\eta_{P V}=\frac{100 \times E_{D}}{G_{T} \times A_{m}}(\%)
$$

The system efficiency $\left(\eta_{S}\right)$ represents the performance of the entire PV system installed and is calculated by the Equation (7) and the inverter efficiency $\left(\eta_{I}\right)$ by the Equation (8):

$$
\begin{gathered}
\eta_{S}=\frac{100 \times E_{A}}{G_{T} \times A_{m}}(\%) \\
\eta_{I}=\frac{100 \times E_{A}}{E_{D}}(\%)
\end{gathered}
$$

\subsection{Power Quality}

Power quality is needed to check the physical properties of the systems, such as amplitude, frequency, waveform, current and voltage. The most important standards for Colombia are: Electromagnetic Compatibility (IEC 61000-4-7, 2002), Recommended Practices and Requirements for Harmonic Control in Electrical Power Systems (IEEE 519, 1992), Energy Quality (NTC-5001, 2008)), Nominal Voltage and Frequency of Electric Power Systems in Service Networks (NTC-1340, 1998), Regulatory Commission for Energy and Gas (CREG 070,1998; 096, 2000; 084, 2002; 0024, 2005), and finally, the Technical Regulation on electrical installations (RETIE).

\section{Methodology}

In the energy quality studies, the proposed methodology follows the basic steps presented by some authors [47] and the Colombian Technical Standard NTC 5001, the measurement period should be one week with a period aggregation of $10 \mathrm{~min}$ for the long-term or permanent perturbations, and $10 \mathrm{~s}$ for slow and rapid disturbances.

The measurements were recorded at two different points: First, the solar irradiance, wind speed, ambient temperature and panel temperature were recorded as seen in Figure 3. Second, the voltage and current AC/DC were recorded at the point of common coupling (Figure 4).

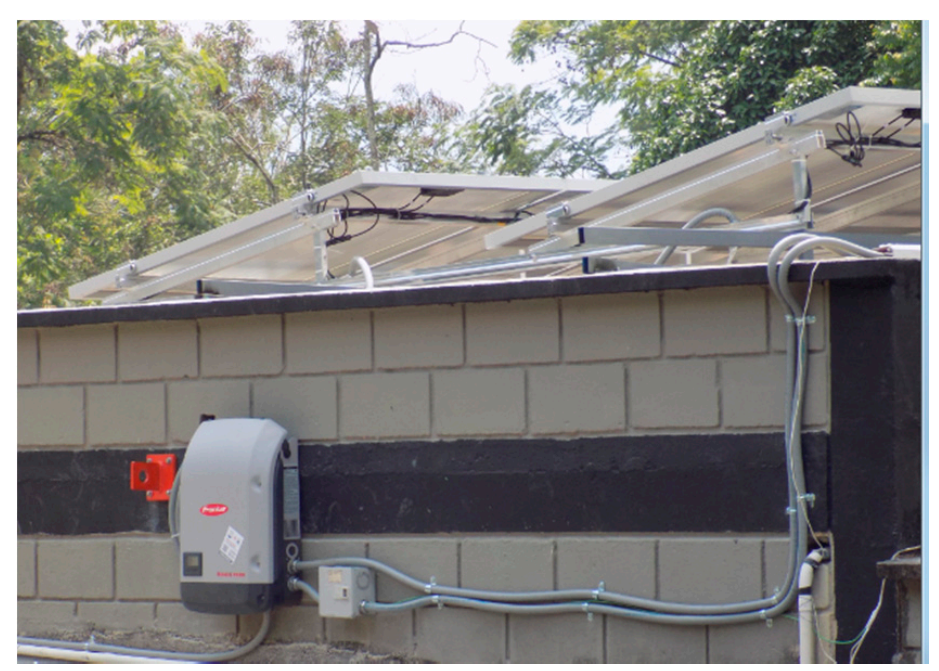

Figure 3. Photovoltaic system on-roof devices. 


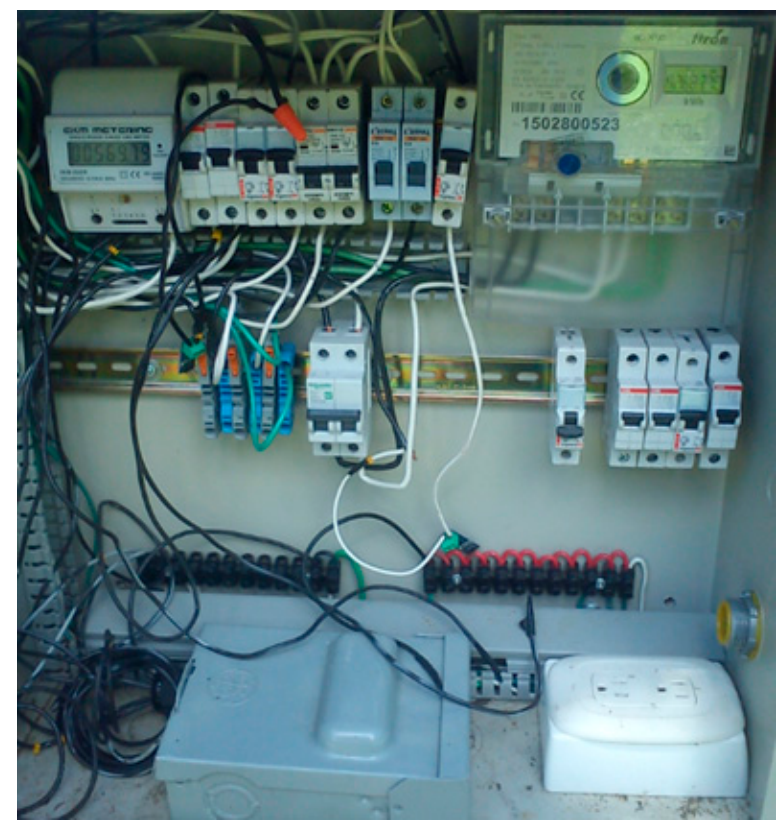

Figure 4. Point of common coupling.

\section{Equipment}

The most important instruments for the measurement of variables of interest in the location are described as follows.

- Turbine Anemometer (model ETAI-30, Erasmus, Ibagué, Colombia). Records the room temperature in the range of -10 to $60^{\circ} \mathrm{C}$, resolution of $0.1^{\circ} \mathrm{C}$ and accuracy of $\pm 2{ }^{\circ} \mathrm{C}$; Also, the wind speed in the range of 0.40 to $30.0 \mathrm{~m} / \mathrm{s}$, with resolution of $0.01 \mathrm{~m} / \mathrm{s}$ and accuracy of $\pm(3 \%+0.2 \mathrm{~m} / \mathrm{s})$.

- Digital clamp multimeter (Erasmus model EPD-1000). Records the AC/DC voltage and current in the range of 0.01 to $1000 \mathrm{~A}$ and 0 to $600 \mathrm{~V}$, resolution of $0.01 \mathrm{~A}$ and $0.01 \mathrm{~V}$, accuracy of $\pm 5 \%$ for both, AC/DC voltage and current.

- Solar energy meter (Erasmus model ES-2000). Records the solar irradiation in the range of 0 to $1999 \mathrm{~W} / \mathrm{m}^{2}$, resolution of $1 \mathrm{~W} / \mathrm{m}^{2}$ and accuracy of $\pm 5 \%$.

- Infrared Pyrometer (model 94920/EM520, All-sun, Ibagué, Colombia). Records the temperature without surface contact in the range of -20 to $520^{\circ} \mathrm{C}$, resolution of $0.1{ }^{\circ} \mathrm{C}$ and accuracy of $\pm 2 \%$.

- Power analyzer (model PW 3360-21, HIOKI, Ibagué, Colombia). Effective Range: Voltage: $90 \mathrm{~V}$ to 780 V; Peak: $\pm 1.400 \mathrm{~V}$; Current: $5 \%$ to $110 \%$ of range; Power: $5 \%$ to $110 \%$ of range; Frequency: $45 \mathrm{~Hz}$ to $66 \mathrm{~Hz}$.

\section{Results and Discussion}

The variables described above were measured to calculate the energy production, the system efficiencies, losses, as well as calculation of evaluation parameters and power quality.

\subsection{System Efficiency}

Figure 5 shows the maximum energy output of the photovoltaic system in March 2016 with $72.65 \%(850 \mathrm{kWh})$ of the total installed capacity $(1170 \mathrm{kWh})$. This percentage is similar to those found by $[48,49]$, which recorded $70 \%$; Moreover, it is very close to the values between $80 \%$ and $100 \%$ given in other references [50]. 


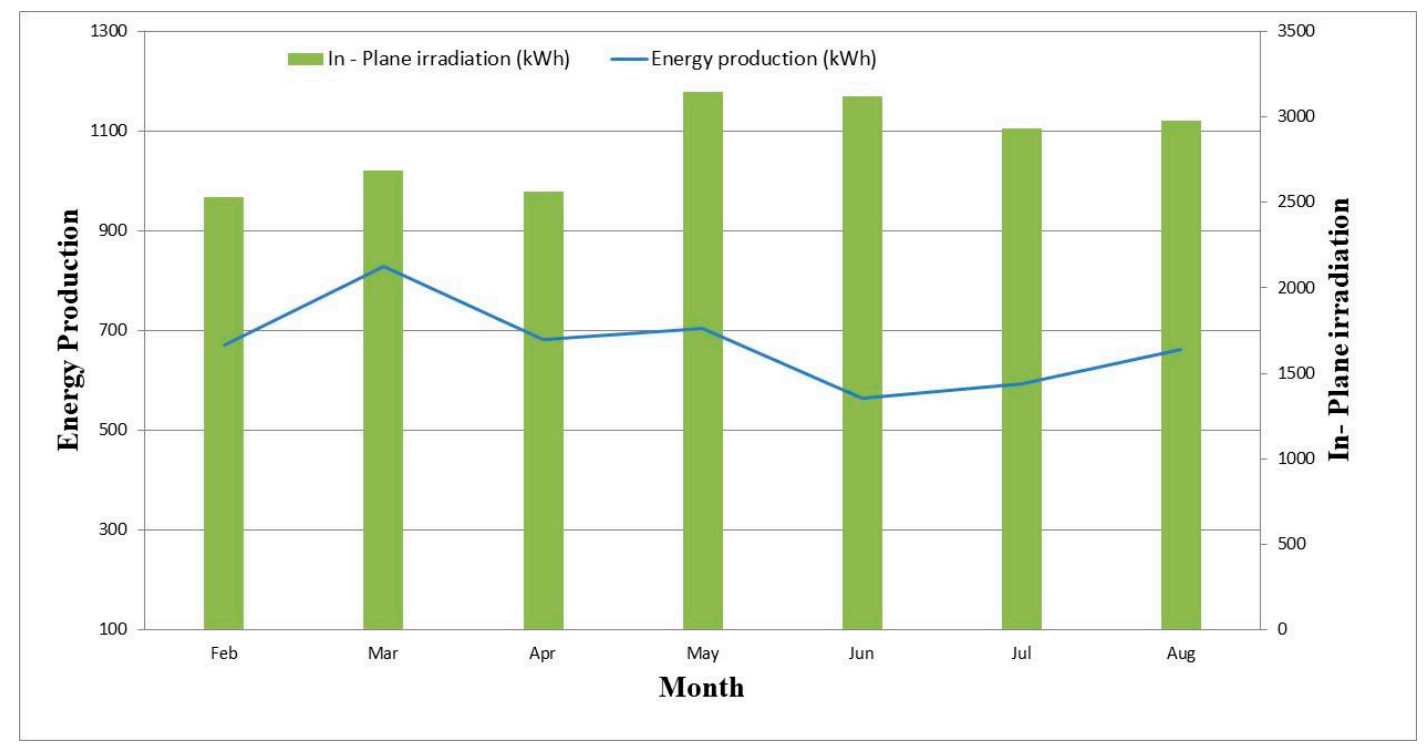

Figure 5. Monthly energy production and in-plane irradiation.

The lowest production was obtained in June 2016 with $49.42 \%$ ( $578.21 \mathrm{kWh})$, due to the high cloudiness and the rainy season. In a 7-month period, $4707.14 \mathrm{kWh}$ was produced with a monthly average of $672.45 \mathrm{kWh}$. Considering that the average is kept for a year, energy produced will be $8069.4 \mathrm{kWh}$.

The final energy produced during the period divided by the nominal power of the system is $1034.5 \mathrm{kWh} / \mathrm{kWp}$, a value that is lower than that found in cities and countries like Tiruchirappalli (India), $1600 \mathrm{kWh} / \mathrm{kWp}$; Málaga (Spain), $1339 \mathrm{kWh} / \mathrm{kWp}$; Crete (Greece) $1336.4 \mathrm{kWh} / \mathrm{kWp}$; Calabria (Italy) $1230 \mathrm{kWh} / \mathrm{kWp}$; Israel $1840 \mathrm{kWh} / \mathrm{kWh}$ and India $1372 \mathrm{kWh} / \mathrm{kWh}$, and higher than those recorded in countries such as The Netherlands $700 \mathrm{kWh} / \mathrm{kWh}$; Germany $730 \mathrm{kWh} / \mathrm{kWp}$ and Switzerland $790 \mathrm{kWh} / \mathrm{kWp}$ [33].

The lowest solar irradiation value was registered during February and the highest was in May. In the other hand, ambient temperature ranged from $25.1^{\circ} \mathrm{C}$ in June to $35.99^{\circ} \mathrm{C}$ in May, showing an upward trend and wind speed ranged from $0.3 \mathrm{~m} / \mathrm{s}$ to $1.1 \mathrm{~m} / \mathrm{s}$. Solar radiation presents a maximum value of $820 \mathrm{~W} / \mathrm{m}^{2} /$ month at 11:00 and a minimum of $200 \mathrm{~W} / \mathrm{m}^{2} /$ month at $16: 00 \mathrm{~h}$, remaining constant between 11:00 and 14:00 $\mathrm{h}$.

In contrast, the equation that correlates the electrical energy output $\left(E_{A}\right)$ with the solar radiation $(\mathrm{G})$ is $E_{A}=3.769 \mathrm{G}-613.8$ with a correlation coefficient of 0.929 . Figure 6 shows that the output power $\left(E_{A}\right)$ has a linear relationship with solar radiation. The importance of an equation like this is that it makes possible to evaluate the generation of energy using photovoltaic power systems, only by identifying the solar radiation.

The error rate obtained with the equation is, within the experimental uncertainty, higher than the values presented by [29] (5\%), and lower than those reported by [32] (15\%). The differences could be due to the specific characteristics of each photovoltaic system, the manufacturers and the climatic conditions.

Subsequently, in Figure 7, it is observed that the lowest values of the monthly reference mean $\left(Y_{R}\right)$, Module $\left(Y_{m}\right)$ and final yields $\left(Y_{F}\right)$ coincide with the rainy season and are $3.0 \mathrm{kWh} / \mathrm{kWp} /$ day, $2.8 \mathrm{kWh} / \mathrm{kWp} /$ day and $2.6 \mathrm{kWh} / \mathrm{kWp} /$ day, respectively, during the months of June and July 2016. The highest reference performance values of $3.9 \mathrm{kWh} / \mathrm{kWp} /$ day were recorded in May 2016, the yields of the modules and final were $3.5 \mathrm{kWh} / \mathrm{kWp} /$ day and $3.2 \mathrm{kWh} / \mathrm{kWp} /$ day for the March 2016, respectively.

Monthly averages were also obtained during the measurement period of $Y_{R}, Y_{m}$ and $Y_{F}$ of $3.4 \mathrm{kWh} / \mathrm{kWp} /$ day, $3.2 \mathrm{kWh} / \mathrm{kWp} /$ day and $3.0 \mathrm{kWh} / \mathrm{kWp} /$ day, respectively. Due to the energy 
losses that occur in the DC/AC conversion in the inverter, the differences presented in the $Y_{F}$ and $Y_{m}$ values are justified, since the room temperature for Ibagué oscillates between 16 and $29^{\circ} \mathrm{C}$ and some authors [51] have observed that for every $12{ }^{\circ} \mathrm{C}$ increase in ambient temperature the efficiency of the inverter drops approximately $1 \%$.

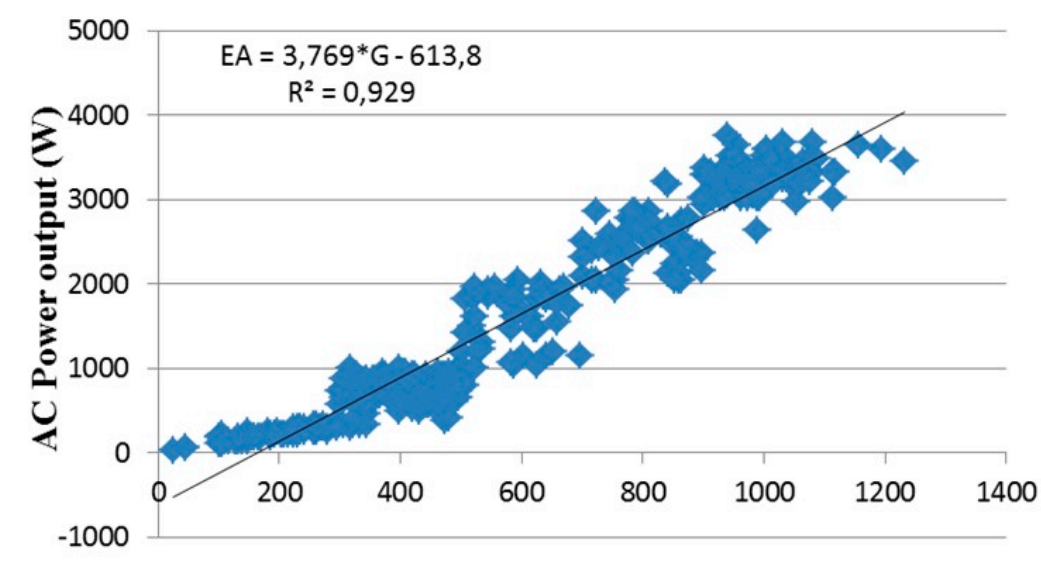

\section{Solar radiation $\left(\mathbf{W} / \mathbf{m}^{2}\right)$}

Figure 6. AC power output of the PV system and solar radiation.

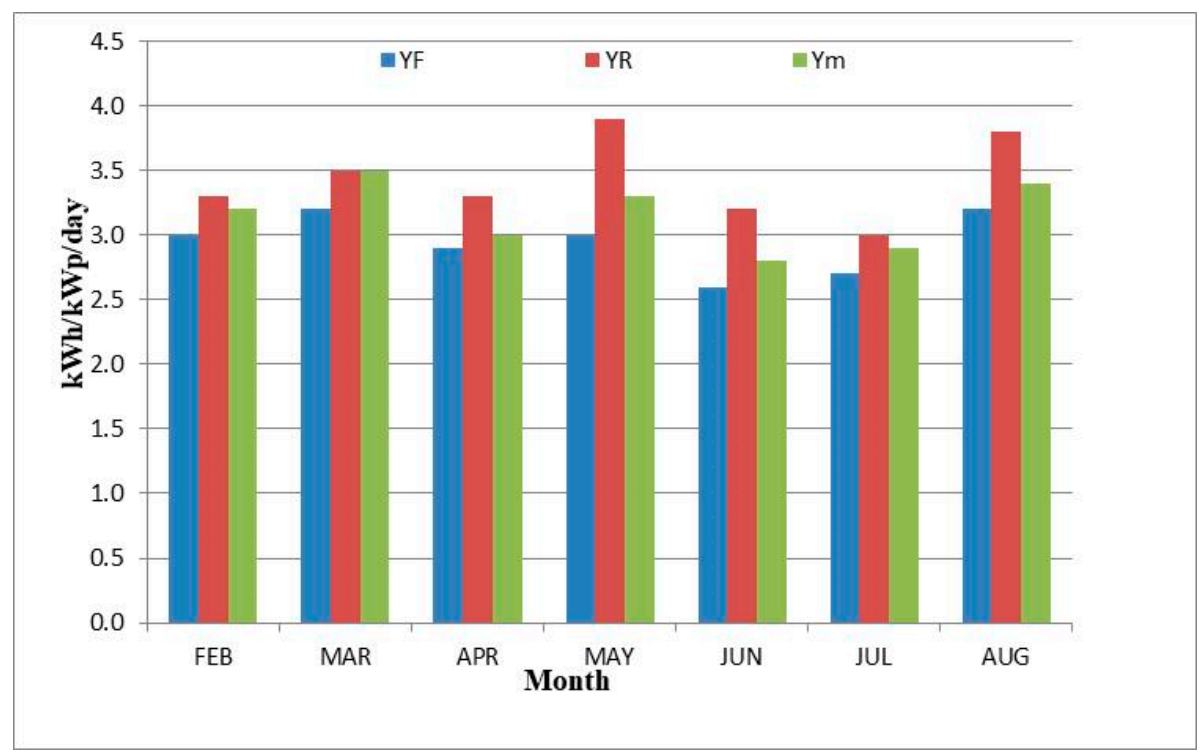

Figure 7. Monthly average daily yields.

The average final yield of the present study was $3.0 \mathrm{kWh} / \mathrm{kWp} /$ day, being lower than that found in cities such as Nicosia (Cyprus), where the average final yield was $4.3 \mathrm{kWh} / \mathrm{kWp} /$ day, Sawda (Kuwait) with a final yield of $4.5 \mathrm{kWh} / \mathrm{kWp} /$ day [29] and Ceará (Brazil) with a final yield of $4.6 \mathrm{kWh} / \mathrm{kWp} /$ day [52]. The difference is that Ibagué has a predominantly dry tropical climate and in the cities of Nicosia, Sawda and Ceará the climate is semi-arid.

The largest losses of the modules $\left(L_{m}\right)$ occurred in May with a value of $0.9 \mathrm{kWh} / \mathrm{kWp} /$ day and the lowest in March of $0.3 \mathrm{kWh} / \mathrm{kWp} /$ day, Figure 8, values corresponding to $23.08 \%$ and $9 \%$ of the reference yields of the respective months. The values found are similar to those reported in the literature for cities such as Rajkot (India), where capture losses were $22.27 \%$ and $3.79 \%$ of the respective reference yields [53]; the number in Singapore was $22.66 \%$ and $17.06 \%$ [46] and Ceará (Brazil) with $22.5 \%$ and $2.3 \%$ [52], respectively. 
In addition, the losses in the system varied from $0.30 \mathrm{kWh} / \mathrm{kWp} /$ day in March to $0.10 \mathrm{kWh} / \mathrm{kWp} /$ day in April, corresponding to $9.0 \%$ and $3.0 \%$ of the respective reference yields. The values found are higher than those reported in cities such as Singapore of 5.55\% and 5.06\% [46] and Fortaleza (Brazil), with $5.7 \%$ and $4.2 \%$ [52] and lower than in Mauritania of 26.3\% and 3.55\% [44], Lesotho with $18.57 \%$ and $10.34 \%$ [33] and Ireland with $22.23 \%$ and $2.89 \%$ [54].

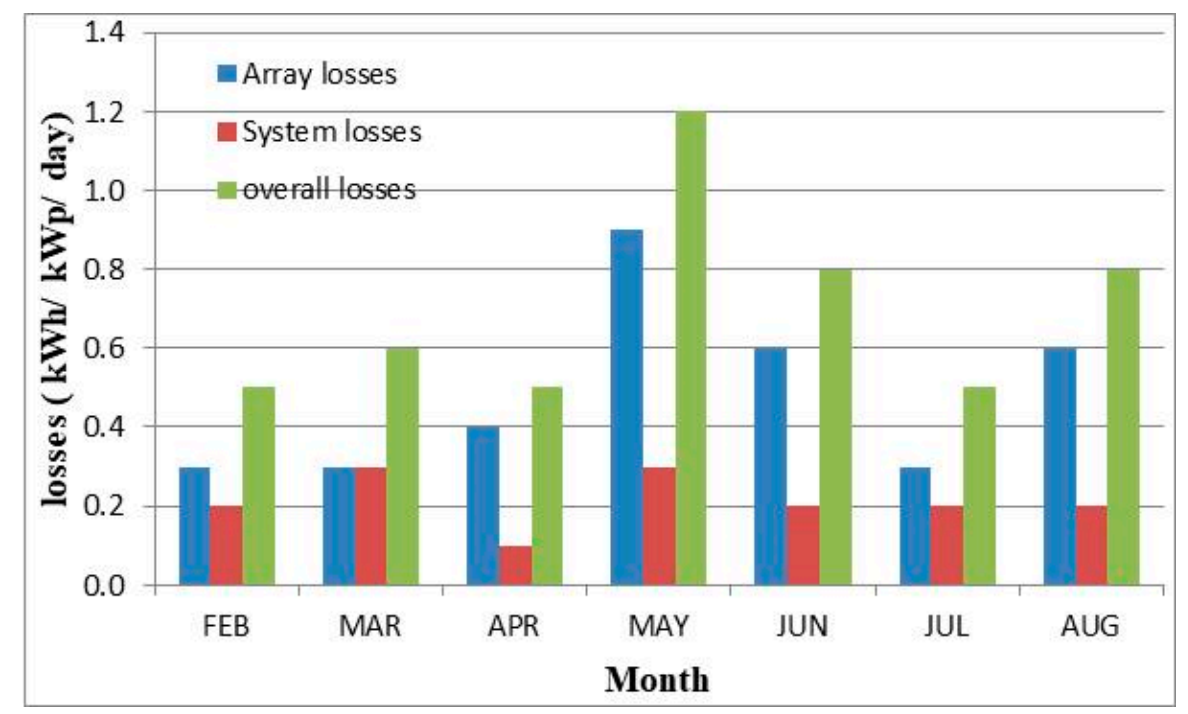

Figure 8. Average daily array capture, system and overall losses.

On the other hand, the maximum total loss ocurred in May and the minimum in April with values of $1.1 \mathrm{kWh} / \mathrm{kWp} /$ day and $0.4 \mathrm{kWh} / \mathrm{kWp} /$ day, respectively. These values correspond to $29 \%$ and $12 \%$ of the respective reference yields. The values differed very little from those reported by [52] of $27.1 \%$ and $6 \%$. The average annual loss of the inverter and total losses was $0.5 \mathrm{kWh} / \mathrm{kWp} / \mathrm{day}$, $0.20 \mathrm{kWh} / \mathrm{kWp} /$ day and $0.7 \mathrm{kWh} / \mathrm{kWp} /$ day, respectively. These values are lower than those reported from $0.71 \mathrm{kWh} / \mathrm{kWp} /$ day, $0.27 \mathrm{kWh} / \mathrm{kWp} /$ day and $1.05 \mathrm{kWh} / \mathrm{kWp} /$ day [52].

To continue, in Figure 9, the highest efficiency values of the modules, the system and the inverter were obtained during March and April with values of $21 \%, 18 \%$ and $94 \%$, respectively. The lowest in May and June with values of $15 \%, 12 \%$ and $74 \%$, respectively. The average monthly efficiency of the modules, the system and the investor during the registration period are $17.6 \%, 14.3 \%$ and $82.8 \%$, respectively. The maximum values are found early in the morning and the minimum values at the end of the day.

Besides, the highest efficiency occurred in March with an average value of $21 \%$, and the lowest in May with 15\% Figure 10. These results are similar to the $15.9 \%$ obtained in the laboratory under controlled conditions, as well as the range of $15-20 \%$, found in the literature [55]. During the first three months of operation the efficiency is high, but from this point it decreases due to the effects of soiling caused by contamination. This coincides with the case of a similar system presented by [56] and also with the time recommended by the manufacturer to do the maintenance in the solar panels.

Lastly, the efficiency of photovoltaic modules is not affected in the irradiation interval between 400 and $1000 \mathrm{~W} / \mathrm{m}^{2}$, being consistent with what is expressed in [55]. The average efficiency of the inverter was in the range of $75-94 \%$ for the different values of irradiation. These results are comparable with the efficiency reported by the manufacturer of $96.9 \%$; also, they are similar to those found in studies conducted in Europe and the United States with mean values of $88 \%$ for Fronius inverters [57]. 


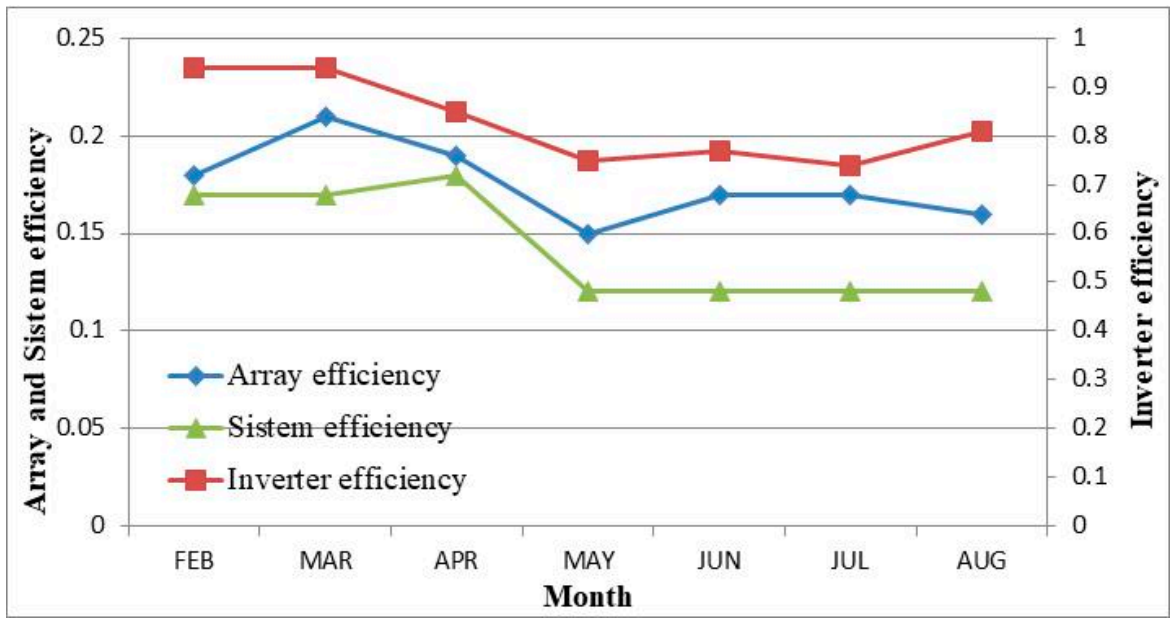

Figure 9. Average array, system and inverter efficiencies.

\subsection{Power Quality at the Point of Common Coupling}

When comparing the measurements of active power before and after the installation of the photovoltaic solar system, Figures 10 and 11 showed no significant difference, during the academic term there was a maximum consumption of $190 \mathrm{kWh} /$ day and a minimum of $30 \mathrm{kWh} /$ day. During Sunday, a decrease in consumption of $8 \mathrm{kWh} /$ day from 10:00 a.m. to 3:00 p.m., coinciding with the period of operation of the photovoltaic system and the absence of academic activity at the Universidad de Ibagué. Therefore, it is confirmed that the photovoltaic system contributes to the active energy consumption, being visible in periods of low demand. The reactive power consumption increased by $7 \%$ in relation to the maximum value recorded and $40 \%$ in relation to the minimum obtained.

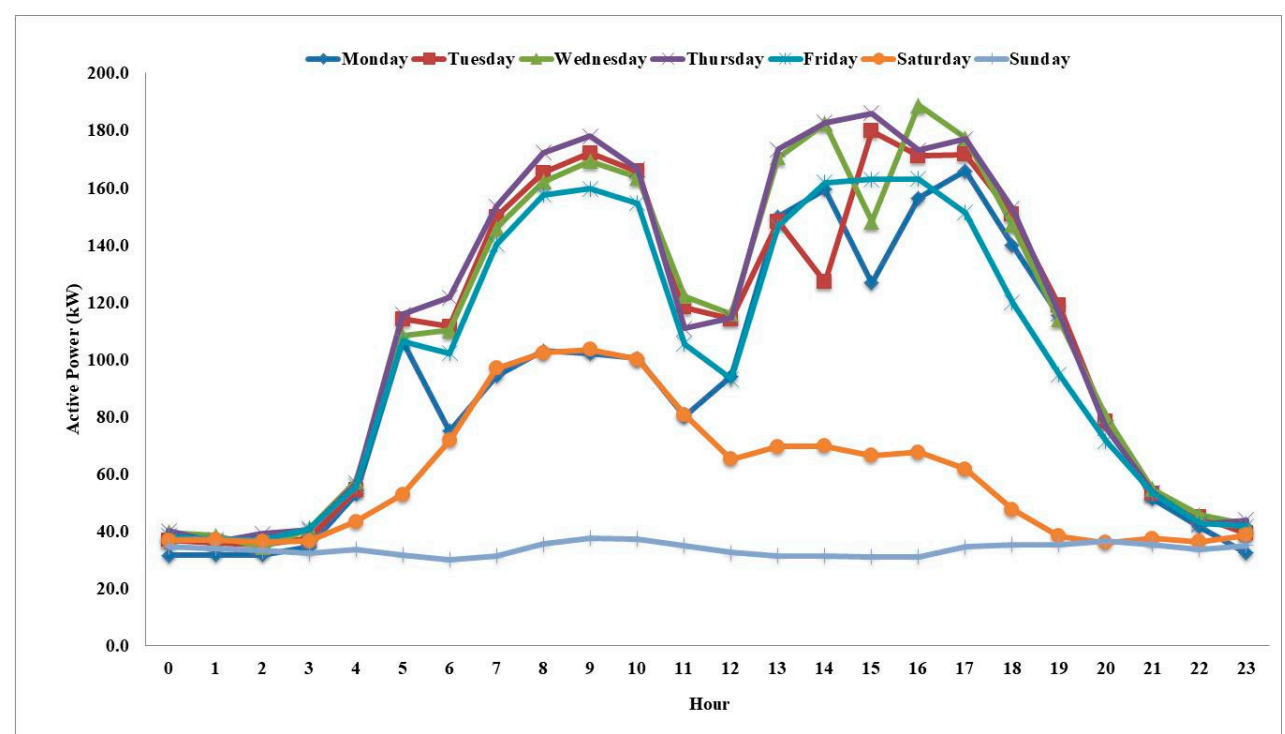

Figure 10. Active Power Consumption.

Regarding the variation of the steady-state voltage, before and after the installation of the photovoltaic system, there is no negative impact on the lines $\left(U_{1}, U_{2}\right.$ and $\left.U_{3}\right)$, according to the guidelines of standards NTC 5001, IEC 038 and EM 50160, there were no overvoltages or undervoltages. Figures 12 and 13 represent the percentage of the recorded voltage values compared to the declared RMS voltage values $(120 \mathrm{~V})$. 


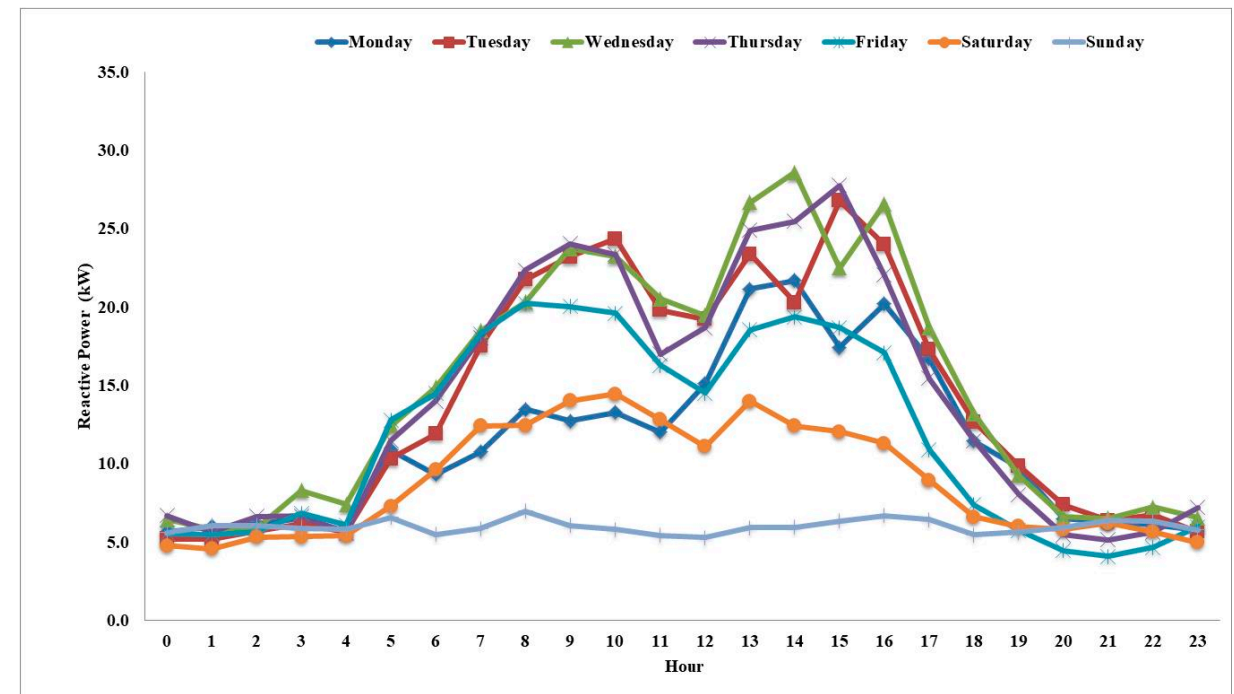

Figure 11. Reactive Power Consumption.

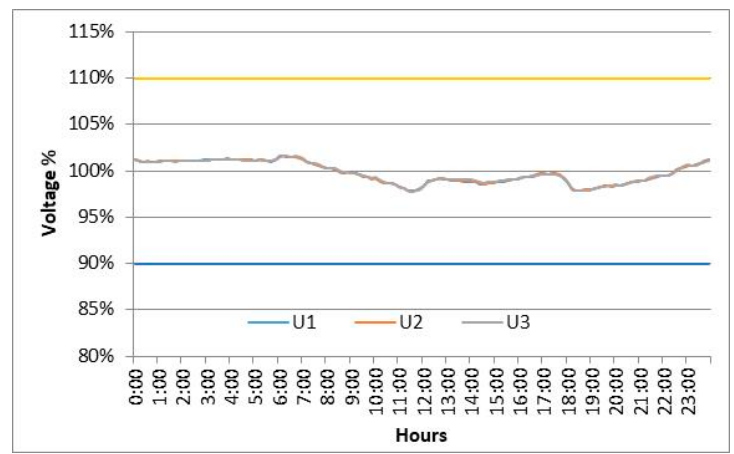

Figure 12. Comparison of the variation of the tension in steady state before the installation of the experimental system.

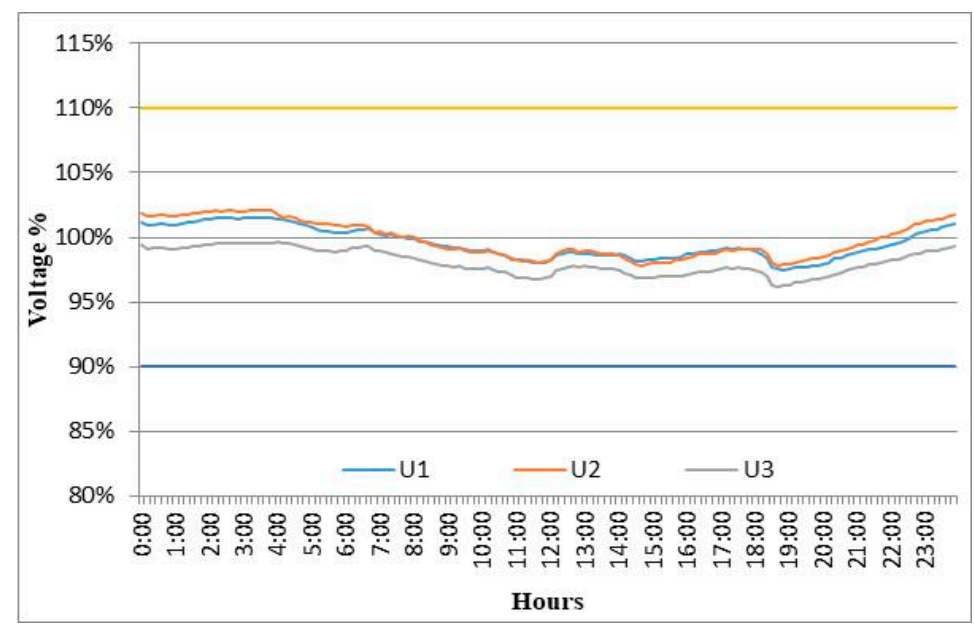

Figure 13. Comparison of the variation of the tension in steady state after the installation of the experimental system.

The maximum percentage obtained was of $102.87 \%$ and the minimum of $94.08 \%$ with respect to the standard value of $100 \%$ proposed by the NTC 5001. The value of the voltage after installing the 
experimental system is more stable because the inverter only injects energy when it is in synchronism with the network (Figure 6), the value of the voltage registered an increase of $7.88 \%, 5.87 \%$ and $6.27 \%$ in the lines $\mathrm{U}_{3}, \mathrm{U}_{2}$ and $\mathrm{U}_{1}$, after installing the experimental system. The values found are similar to those reported by $[58,59]$, who found very small increases, that in some cases reached $2 \%$.

The voltage unbalance is maintained within the ranges established by NTC 5001 before and after the connection of the photovoltaic system (Table 3). When installing the experimental system the value of the average voltage is very close to the value of the registered voltage, that is to say, the standard deviation is smaller and the value of the voltage is more stable, this causes the unbalance factor to be improved. However, it registers an increase of 3.5\% and $70 \%$ with respect to the maximum and minimum values, respectively. These results go along with the suggestions made by some authors [60] that show the possibility of an increase in the voltage unbalance with the installation of photovoltaic systems in low voltage grids.

Table 3. Comparison of voltage unbalance.

\begin{tabular}{ccccccc}
\hline \multirow{2}{*}{ Variable } & \multicolumn{2}{c}{ Before } & \multicolumn{2}{c}{ After } & \multicolumn{2}{c}{ Standard } \\
\cline { 2 - 7 } & Maximum & Minimum & Maximum & Minimum & Maximum & Minimum \\
\hline Voltage unbalance & $1.72 \%$ & $1.10 \%$ & 1.66 & 0.33 & $2.00 \%$ & $2.00 \%$ \\
\hline
\end{tabular}

Short and long term flicker measurements before and after installation of the photovoltaic network is within the range established by NTC 5001 and EM 50160 (Tables 4 and 5). The maximum and minimum values obtained during short-duration flicker measurements were 0.35 and 0.10 p.u., respectively. The long duration flicker recorded a maximum value of 0.20 p.u. and a minimum of $0.09 \mathrm{p} . \mathrm{u}$. The values obtained from the flicker variation that short and long duration are below those reported in the literature [61], who found a value of 0.38 p.u. in short duration flicker measurements in a photovoltaic system connected to the low voltage network $7.2 \mathrm{kWp}$. Similar studies performed by [62] recorded long-duration flicker values of 0.36 p.u.

Table 4. Comparison of short duration flicker (PST).

\begin{tabular}{ccccccc}
\hline \multirow{2}{*}{ Line } & \multicolumn{2}{c}{ Before } & \multicolumn{2}{c}{ After } & \multicolumn{2}{c}{ Standard } \\
\cline { 2 - 7 } & Maximum & Minimum & Maximum & Minimum & Maximum & Minimum \\
\hline $\mathrm{U}_{1}$ & 0.30 p.u. & 0.10 p.u. & 0.30 p.u. & 0.10 p.u. & 1.00 p.u. & 1.00 p.u. \\
$\mathrm{U}_{2}$ & 0.32 p.u. & 0.10 p.u. & 0.35 p.u. & 0.15 p.u. & 1.00 p.u. & 1.00 p.u. \\
$\mathrm{U}_{3}$ & 0.27 p.u. & 0.10 p.u. & 0.25 p.u. & 0.10 p.u. & 1.00 p.u. & 1.00 p.u. \\
\hline
\end{tabular}

Table 5. Comparison of long duration flicker (PLT).

\begin{tabular}{ccccccc}
\hline \multirow{2}{*}{ Line } & \multicolumn{2}{c}{ Before } & \multicolumn{2}{c}{ After } & \multicolumn{2}{c}{ Standard } \\
\cline { 2 - 7 } & Maximum & Minimum & Maximum & Minimum & Maximum & Minimum \\
\hline $\mathrm{U}_{1}$ & 0.19 p.u. & 0.09 p.u. & 0.19 p.u. & 0.09 p.u. & 0.65 p.u. & 0.65 p.u. \\
$\mathrm{U}_{2}$ & 0.19 p.u. & 0.10 p.u. & 0.20 p.u. & 0.10 p.u. & 0.65 p.u. & 0.65 p.u. \\
$\mathrm{U}_{3}$ & 0.20 p.u. & 0.10 p.u. & 0.20 p.u. & 0.09 p.u. & 0.65 p.u. & 0.65 p.u. \\
\hline
\end{tabular}

The values of total voltage harmonics (THD) that were recorded before and after the operation of the photovoltaic system are lower than the $5.0 \%$ value established by NTC 5001 (Table 6 ). The maximum value obtained was $3.75 \%$ and the minimum of $1.70 \%$. However, in all the lines, it is possible to identify an increase of $7 \%$ for line $\mathrm{U}_{1}, 0.8 \%$ in $\mathrm{U}_{2}$ and $3 \%$, in line $\mathrm{U}_{3}$. Increases are produced by leakage currents that increase harmonics and electromagnetic emissions in the existing power structure [62]. When the inverter operates with a relative power greater than $20 \%$ and the voltage is sinusoidal, the current injected into the network by the inverter is also sinusoidal with low harmonic content; therefore, a high 
quality inverter can have harmonics content levels limited to those established by technical standards in the highest possible power range. However, when the relative power is less than $20 \%$, depending on the manufacturer, the inverters can present currents with harmonic distortion levels higher than the values established by the technical standards. The total harmonic distortion tends to increase when the load level of the inverter decreases, regardless of the impedance of the network. Is possible to find situations where the reactive electrical charges at the connection point interfere with the harmonic current. Another reference also found an increase between $0.7 \%$ and $2.5 \%$ in an $8 \mathrm{kWp}$ system [63].

The total current harmonics (TDDI) recorded and compared to the NTC 5001 are outside the established range (Table 7), with a maximum value of $17.80 \%$ and minimum of $0.80 \%$. The values recorded before and after the implementation of the photovoltaic system do not present significant differences for the lines $U_{2}$ and $U_{3}$, in line $U_{1}$, an increase $22 \%$ was obtained. This increase is consistent with that reported by some authors [64] and similar to that reported by [63], who found values between 2 and $38 \%$ when studying an experimental network of $8 \mathrm{kWp}$.

Table 6. Comparison of Total Voltage Harmonic Distortion (THD).

\begin{tabular}{ccccccc}
\hline \multirow{2}{*}{ Line } & \multicolumn{2}{c}{ Before } & \multicolumn{2}{c}{ After } & \multicolumn{2}{c}{ Standard } \\
\cline { 2 - 6 } & Maximum & Minimum & Maximum & Minimum & Maximum & Minimum \\
\hline $\mathrm{U}_{1}$ & $3.18 \%$ & $2.21 \%$ & $3.40 \%$ & $1.70 \%$ & $5.00 \%$ & $5.00 \%$ \\
$\mathrm{U}_{2}$ & $3.72 \%$ & $2.13 \%$ & $3.75 \%$ & $1.80 \%$ & $5.00 \%$ & $5.00 \%$ \\
$\mathrm{U}_{3}$ & $3.42 \%$ & $2.40 \%$ & $3.52 \%$ & $1.80 \%$ & $5.00 \%$ & $5.00 \%$ \\
\hline
\end{tabular}

Table 7. Comparison of Total Harmonic Distortion (TDDI).

\begin{tabular}{ccccccc}
\hline \multirow{2}{*}{ Line } & \multicolumn{2}{c}{ Before } & \multicolumn{2}{c}{ After } & \multicolumn{2}{c}{ Standard } \\
\cline { 2 - 6 } & Maximum & Minimum & Maximum & Minimum & Maximum & Minimum \\
\hline $\mathrm{U}_{1}$ & 9.00 & 0.80 & 11.00 & 0.80 & 5.00 & 5.00 \\
$\mathrm{U}_{2}$ & 17.00 & 3.00 & 17.80 & 2.50 & 5.00 & 5.00 \\
$\mathrm{U}_{3}$ & 16.80 & 3.00 & 16.50 & 2.00 & 5.00 & 5.00 \\
\hline
\end{tabular}

The power factor was not affected by the operation of the photovoltaic system (Table 8), and a maximum value of 0.98 and a minimum of 0.85 were obtained, in compliance with the guidelines of NTC 5001. These values are in agreement with [65-67] which state that the power factor must be greater than 0.85 if the recording at the output of the photovoltaic system is greater than $10 \%$ of the capacity. The power factor of the inverter is a function of the load level and increases proportionally to the relative power, approaching $100 \%$ when it is working with the nominal output power. For inverters that operate above $30 \%$ of the rated power, the power factor is greater than $90 \%$ and for values below $30 \%$, the power factor is lower.

Table 8. Comparison of power factor values.

\begin{tabular}{ccccccc}
\hline \multirow{2}{*}{ Variable } & \multicolumn{2}{c}{ Before } & \multicolumn{2}{c}{ After } & \multicolumn{2}{c}{ Standard } \\
\cline { 2 - 6 } & Maximum & Minimum & Maximum & Minimum & Maximum & Minimum \\
\hline Power Factor & 0.98 & 0.85 & 0.98 & 0.90 & 1.00 & 0.90 \\
\hline
\end{tabular}

The total active and reactive power were increased by $58 \%$ and $42 \%$ after the photovoltaic system started operating (Tables 9 and 10). The registered maximum value of active and reactive power was $33.88 \mathrm{~kW}$ and $9.5 \mathrm{~kW}$, respectively. The reduction of the power during the faults on the network is a major problem for DG power plants. The deeper the network failure, the higher the reactive power requirements of the network operators [68]. In extreme cases, $100 \%$ of the reactive current is required. 
However, in gaps produced far from the connection point, both active and reactive power must be injected to feed and support the network simultaneously. Excess production must be eliminated from the system to avoid overvoltage and inverter trip, if the network voltage drops, the inverter injects capacitive reactive current to increase it and if it increases, the inverter injects inductive current to decrease it, these voltage variations of the network change the active and reactive power after the installation of the PV photovoltaic system.

Table 9. Total active power values $\mathrm{kW}$.

\begin{tabular}{ccccccc}
\hline \multirow{2}{*}{ Variable } & \multicolumn{2}{c}{ Before } & \multicolumn{2}{c}{ After } & \multicolumn{2}{c}{ Standard } \\
\cline { 2 - 7 } & Maximum & Minimum & Maximum & Minimum & Maximum & Minimum \\
\hline Total Active Power & 21.50 & 4.00 & 33.88 & 3.00 & N.A & N.A \\
\hline
\end{tabular}

Table 10. Total reactive power values $\mathrm{kW}$.

\begin{tabular}{ccccccc}
\hline \multirow{2}{*}{ Variable } & \multicolumn{2}{c}{ Before } & \multicolumn{2}{c}{ After } & \multicolumn{2}{c}{ Standard } \\
\cline { 2 - 7 } & Maximum & Minimum & Maximum & Minimum & Maximum & Minimum \\
\hline Total Reactive Power & 5.50 & 1.50 & 9.50 & 1.50 & N.A & N.A \\
\hline
\end{tabular}

The maximum and minimum temperatures obtained at the common connection point before the photovoltaic system came into operation were $34.3^{\circ} \mathrm{C}$ and $31.4^{\circ} \mathrm{C}$, respectively (Figure 14). Once the system came into operation, the maximum and minimum temperatures recorded were $36.9^{\circ} \mathrm{C}$ and $33.7^{\circ} \mathrm{C}$, respectively (Table 11). Therefore, the increase at the common point of connection of the temperature is $7.5 \%$. This increase is within the requirements established by the NTC 2050 and the BWG.

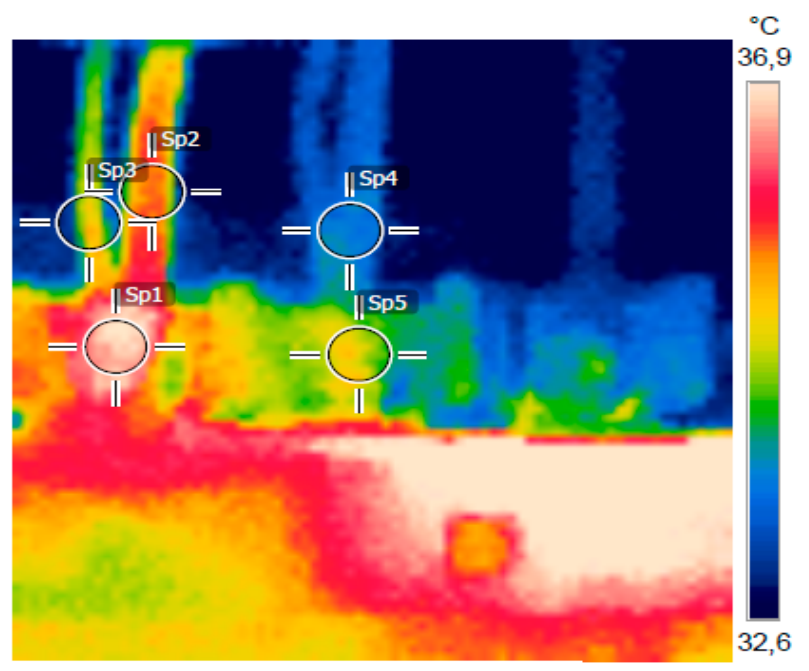

Figure 14. Thermographic analysis.

Table 11. Results of the thermographic analysis before and after the operation of the photovoltaic system.

\begin{tabular}{cccc}
\hline Measurement & Before & After & NTC 2050 \\
\hline Sp1 & $34.3^{\circ} \mathrm{C}$ & $35.1^{\circ} \mathrm{C}$ & $70{ }^{\circ} \mathrm{C}$ \\
Sp2 & $34.2^{\circ} \mathrm{C}$ & $33.7^{\circ} \mathrm{C}$ & $70{ }^{\circ} \mathrm{C}$ \\
Sp3 & $32.4^{\circ} \mathrm{C}$ & $36.9^{\circ} \mathrm{C}$ & $70^{\circ} \mathrm{C}$ \\
Sp4 & $31.4^{\circ} \mathrm{C}$ & $35.0^{\circ} \mathrm{C}$ & $70{ }^{\circ} \mathrm{C}$ \\
Emissivity & 0.8 & 0.8 & - \\
Reflection Temperature & $28{ }^{\circ} \mathrm{C}$ & $28^{\circ} \mathrm{C}$ & - \\
\hline
\end{tabular}




\section{Conclusions}

A study of a photovoltaic system of $7.8 \mathrm{kWp}$ connected to the low voltage electrical grid belonging to the Universidad de Ibagué Colombia, from February to August 2016, determining its performance parameters and the energy quality at the common point of connection, is reported. The total energy produced was $8069.4 \mathrm{kWh}$ and the final energy produced during the period divided by the nominal power of the system is $1034.5 \mathrm{kWh} / \mathrm{kWh}$. The benchmark performance, module performance and final performance values ranged from a minimum to a maximum of 3.0-3.9 kWh $/ \mathrm{kWp} /$ day; $2.8-3.5 \mathrm{kWh} / \mathrm{kWp} /$ day and 2.6-3.2 kWh/kWp/day, respectively. The average annual losses in the module, inverter and total losses were $0.5 \mathrm{kWh} / \mathrm{kWp} /$ day, $0.20 \mathrm{kWh} / \mathrm{kWp} /$ day and $0.7 \mathrm{kWh} / \mathrm{kWp} /$ day. The average monthly efficiency of the modules, the system and the investor during the registration period are $17.6 \%, 14.3 \%$ and $82.8 \%$, respectively. Reactive power consumption increased between $7 \%$ and $40 \%$. The voltage unbalance registers an increase of $3.5 \%$ and $70 \%$ with respect to the maximum and minimum values, respectively. The maximum and minimum value obtained during short and long duration flicker measurements was 0.35 p.u., 0.20 p.u. and 0.10 p.u., 0.09 p.u., respectively. The values of total voltage harmonics (THD) increased by $7 \%$ for the $\mathrm{U}_{1}$ line, $0.8 \%$ for $\mathrm{U}_{2}$ and $3 \%$ for the $\mathrm{U}_{3}$ line, and TDDI current harmonics recorded a $22 \%$ increase. The total active and reactive power were increased by $58 \%$ and $42 \%$ after the photovoltaic system started operating and the temperature at the common point of connection increased by $7 \%$. The results show the importance of this type of study, because the vast majority of low voltage grids in Colombia are old, they are saturated and any disturbance can cause serious damage to the connected electrical devices. It is important to know the impact on the power quality caused by the installation of photovoltaic systems to the low voltage grid, in order to define the requirements of the network, the type of communication between the photovoltaic system and the operator of the low voltage grid, the necessary protection system, among others.

Author Contributions: A.V.G. and T.M.d.S. conducted the experiments; A.V.G., T.M.d.S. and P.M.S. analyzed the data; A.V.G. and D.F.A.S. edited and improved the manuscript.

Acknowledgments: This work was supported by the Universidad de Ibagué and Universidade Estadual Paulista (UNESP) Câmpus Guaratinguetá under Project 15-333-INT.

Conflicts of Interest: The authors declare no conflict of interest.

\section{References}

1. Jacovides, C.P.; Tymvios, F.S.; Assimakopulous, V.D.; Kaltsounides, N.A. Comparative study of various correlations in estimating hourly diffuse fraction of global solar radiation. Renew. Energy 2006, 31, 2492-2504. [CrossRef]

2. Yang, D.; Yin, H. Energy conversion efficiency of a novel hybrid solar system for photovoltaic, thermoelectric, and heat utilization. IEEE Trans. Energy Convers. 2011, 26, 662-670. [CrossRef]

3. Phuangpornpitak, N.; Kumar, S. User acceptance of diesel/PV hybrid system in an island community. Renew. Energy 2011, 36, 125-131. [CrossRef]

4. Yilmaz, S.; Ozcalik, H.; Kesler, S.; Dincer, F.; Yelmen, B. The analysis of different PV power systems for the determination of optimal PV panels and system installation-A case study in Kahramanmaras, Turkey. Renew. Sustain. Energy Rev. 2015, 52, 1015-1024. [CrossRef]

5. Chouder, A.; Silvestre, S. Automatic supervision and fault detection of PV systems based on power losses analysis. Energy Convers. Manag. 2010, 51, 1929-1937. [CrossRef]

6. Energy Information Administration. Annual Energy Review 2008. 26 June 2009. Available online: https: // www.eia.gov/totalenergy/data / annual/archive/038408.pdf (accessed on 15 May 2015).

7. REN21. September 2011. Available online: http://www.ren21.net/Portals/0/documents/Resources/GSR2011_ FINAL.pdf (accessed on 15 May 2015).

8. Markvart, T. Solar Electricity; Wiley: Chichester, UK; New York, NY, USA, 2000.

9. Caamaño-Martin, E. Edificios Fotovoltaicos Conectados a La Red Electrica: Caracterizacion y Analisis. Ph.D Thesis, E.T.S.I. Telecomunicación (UPM), Madrid, Spain, 1998. 
10. Bagarella, G.; Lazzarin, R.; Noto, M. Annual simulation energy and economic analysis of hybrid heat pump systems for residential buildings. Appl. Therm. Eng. 2016, 99, 485-494. [CrossRef]

11. Pärisch, P.; Mercker, O.; Warmuth, J.; Tepe, R.; Bertram, E.; Rockendor, G. Investigations and model validation of a ground-coupled heat pump for the combination with solar collectors. Appl. Therm. Eng. 2014, 62, 375-381. [CrossRef]

12. Hoseini, M.; Rahdar, A.; Emamzadeh, A. A comparative study on PCM and ice thermal energy storage tank for air-conditioning systems in office buildings. Appl. Therm. Eng. 2016, 96, 391-399. [CrossRef]

13. Mayer, B.; Killian, M.; Kozek, M. Management of hybrid energy supply systems in buildings using mixed-integer model predective control. Energy Convers. Manag. 2015, 98, 470-483. [CrossRef]

14. Shihabudheen, M.; Arun, P. Performance evaluation of a hybrid photovoltaic-thermal water heating system. Int. J. Green Energy 2015, 9, 969-986. [CrossRef]

15. Zafar, S.; Dincer, I. Thermodynamic analysis of a combined Pv/T-fuel cell system for power, heat, fresh water and hydrogen production. Int. J. Hydrogen Energy 2014, 39, 9962-9972. [CrossRef]

16. Herrando, M.; Markides, C.; Hellgardt, K. A UK-based assessment of hybrid PV and solar-thermal systems for domestic heating and power system performance. Appl. Energy 2014, 122, 288-309. [CrossRef]

17. Shaari, S.; Omar, A.M.; Haris, A.H.; Sulaiman, S.I. Solar Photovoltaic Power: Designing Grid-Connected Systems; Kementerian Tenaga, Teknologi Hijau dan Air: Putrajaya, Malaysia, 2010.

18. Alonso-Abella, M. A model for energy production estimation of PV grid connected systems based on energetic losses and experimental data on site diagnosis. In Proceedings of the 19th European Photovoltaic Solar Energy Conference, Paris, France, 7-11 June 2004; pp. 2447-2450.

19. Gabler, H.; Wiemken, E. How much energy will a specific PV system produce? In Proceedings of the Actas del XIII Congreso Europeo de Energia Solar Fotovoltaica, Niza, France, 23-27 October 1995.

20. Ransome, S.J.; Wohlgemuth, J.H. kWh/kWp dependency on PV technology and balance of systems performance. In Proceedings of the Conference Record of the Twenty-Ninth IEEE Photovoltaic Specialists Conference, New Orleans, LA, USA, 19-24 May 2002.

21. Kroposki, B.; Emery, K.; Myers, D.; Mrig, L. A comparison of photovoltaic module performance evaluation methodologies for energy ratings. In Proceedings of the 1994 IEEE 1st World Conference on Photovoltaic Energy Conversion-WCPEC (A Joint Conference of PVSC, PVSEC and PSEC), Waikoloa, HI, USA, 5-9 December 1994.

22. Turcotte, D.; Ross, M.; Sheriff, F. Photovoltaic hybrid system sizing and simulation tools: Status and Needs. In Proceedings of the PV Horizon: Workshop on Photovoltaic Hybrid Systems, Montreal, QC, Canada, 10 September 2001.

23. King, D.L.; Boison, W.E.; Kratochvil, J.A. Energy-Based performance modeling for photovoltaic systems. In Proceedings of the National Center for Photovoltaics and Solar Program Review Meeting, Denver, CO, USA, 24-26 March 2003.

24. Abete, A.; Napoli, R.; Spertino, F. A simulation procedure to predict the monthly energy supplied by grid-connected Pv systems. In Proceedings of the 3rd World Conference on Photovoltaic Energy Conversion, Osaka, Japan, 11-18 May 2003.

25. Šúri, M.; Huld, T.A.; Dunlop, E.D. PV-GIS: A web-based solar radiation database for the calculation of PV potential in Europe. Int. J. Sustain. Energy 2005, 24, 55-67. [CrossRef]

26. Carneiro, J.A.O. Dimensionamento de Sistemas Fotovoltaicos. Ph.D. Thesis, Instituto Politécnico de Bragança, Escola Superior de Tecnologia e de Gestão, Guimaraes, Portugal, 2009.

27. Hernández Mora, J.A. Metodología Para El Análisis Técnico De La Masificación De Sistemas Fotovoltaicos Como Opción De Generación Distribuida En Redes De Baja Tensión; Universidad Nacional de Colombia: Bogota, Colombia, 2012.

28. Patiño Abella, J.S.; Tello Reyes, J.S.; Hernandez Mora, J.A. Diseño e implementación de un sistema fotovoltaico híbrido y desarrollo de su regulador de carga aplicando instrumentación virtual. Elementos 2013. [CrossRef]

29. Adaramola, M.S.; Vagnes, E.E. Preliminary assessment of a small-scale rooftop PV-grid tied in Norwegian climatic conditions. Energy Convers. Manag. 2015, 90, 458-465. [CrossRef]

30. Micheli, D.; Alessandrini, S.; Radu, R.; Casula, I. Analysis of the outdoor performance and efficiency of two grid connected photovoltaic systems in northern Italy. Energy Convers. Manag. 2014, 80, 436-445. [CrossRef] 
31. Diez-Mediavilla, M.; Alonso-Tristan, C.; Rodriguez-Amigo, M.; Garcia-Calderon, T.; Dieste-Velasco, M. Performance analysis of PV plants: Optimization for improving profitability. Energy Convers. Manag. 2012, 54, 17-23. [CrossRef]

32. Ayompe, L.; Duffy, A.; McCormack, S.; Conlon, M. Measured performance of a $1.72 \mathrm{~kW}$ rooftop grid connected photovoltaic system in Ireland. Energy Convers. Manag. 2011, 52, 816-825. [CrossRef]

33. Mpholo, M.; Nchaba, T.; Monese, M. Yield and performance analysis of the first grid-connected solar farm at Moshoeshoe I International Airport, Lesotho. Renew. Energy 2015, 81, 845-852. [CrossRef]

34. Kumar, K.A.; Sundareswaran, K.; Venkateswaran, P. Performance study on a grid connected $20 \mathrm{kWp}$ solar photovoltaic installation in an industry in Tiruchirappalli (India). Energy Sustain. Dev. 2014, 23, $294-304$. [CrossRef]

35. Padmavathi, K.; Daniel, S.A. Performance analysis of a 3 MWp grid connected solar photovoltaic power plant in India. Energy Sustain. Dev. 2013, 17, 615-625. [CrossRef]

36. Marnay, C. Micro-Grids and Heterogeneous Security, Quality, Reliability and Availability. In Proceedings of the Power Conversion Conference, Nagoya, Japan, 2-5 April 2007.

37. Li, Y.; Vilathgamuwa, D.; Loh, P. A Grid-Interfacing Power Quality Enchanced Operation of a Three-Wire Micro-Grid Applications. IEEE Trans. Power Electron. 2006, 21, 1021-1031. [CrossRef]

38. Majumder, R.; Ghosh, A.; Ledwich, G.; Zare, F. Load Sharing and Power Quality Enchanced Operation of a Distributed Micro-Grid. IET Rev. Power Gener. 2009, 3, 109-119. [CrossRef]

39. Shahnia, F.; Majumder, R.; Ghosh, A. Operation and Control of a Hybrid Micro-Grid Containing Unbalanced and Nonlinear Loads. Electr. Power Syst. Res. 2010, 80, 954-965. [CrossRef]

40. Papadimitriou, C.; Vovos, N. Transient Response Improvement of Microgrids Exploiting the Inertia of a Doubly-Fed Induction Generator (DFIG). Energies 2010, 3, 1049-1066. [CrossRef]

41. Zamani, M.; Yazdani, A.; Sidhu, T. A Control Strategy for Enhanced Operation of Inverter-Based Micro-Grids Under Transient Distrubances and Network Faults. IEEE Trans. Power Deliv. 2012, 27, 1737-1747. [CrossRef]

42. Dávi, G.A.; Caamaño-Martin, E.; Rüther, R.; Solano, J. Energy performance evaluation of a net plus-energy residential building with grid-connected photovoltaic system in Brazil. Energy Build. 2016, 120, 19-29. [CrossRef]

43. Adaramola, M.S. Techno-economic analysis of a $2.1 \mathrm{~kW}$ rooftop photovoltaic-grid-tied system based on actual performance. Energy Convers. Manag. 2015, 101, 85-93. [CrossRef]

44. Sidi, C.E.; Ndiaye, M.L.; El Bah, M.; Mbodji, A.; Ndiaye, A.; Ndiaye, P.A. Performance analysis of the first large-scale (15 MWp) grid-connected photovoltaic plant in Mauritania. Energy Convers. Manag. 2016, 119, 411-421. [CrossRef]

45. Sharma, V.; Chandel, S. Performance analysis of a $190 \mathrm{kWp}$ grid interactive solar photovoltaic power plant in India. Energy 2013, 55, 476-485. [CrossRef]

46. Wittkopf, S.; Valliappan, S.; Liu, L.; Ang, K.S.; Cheng, S.C. Analytical performance monitoring of a $142.5 \mathrm{kWp}$ grid-connected rooftop BIPV system in Singapore. Renew. Energy 2012, 47, 9-20. [CrossRef]

47. Santoso, S.; McGranaghan, M.F.; Wayne Beaty, H. Electrical Power Systems Quality, 3rd ed.; McGraw-Hill Education: Berkshire, UK, 2012.

48. Burger, B.; Rüther, R. Inverter sizing of grid-connected photovoltaic systems in the light of local solar resource distribution characteristics and temperature. Solar Energy 2006, 80, 32-45. [CrossRef]

49. Macedo, W.; Zilles, R. Operational results of grid-connected photovoltaic system with different inverter's sizing factors (ISF). Prog. Photovolt. Res. Appl. 2007, 15, 337-352. [CrossRef]

50. Islam, S.; Woyte, A.; Belmans, R.; Nijs, J. Undersizing inverters for grid connection-What is the optimum? In Proceedings of the PV in Europe, Rome, Italy, 7-11 October 2002.

51. Vignola, F.; Mavromatakis, F.; Krumsick, J. Performance of Inverters. In Proceedings of the 37th ASES Annual Conference, San Diego, CA, USA, 3-8 May 2008.

52. Lutero, C.; Ferreira, L.; Francisco, H.B. Performance analysis of a grid connected photovoltaic system in northeastern Brazil. Energy Sustain. Dev. 2017, 37, 79-85.

53. Dobaria, B.; Pandya, M.; Aware, M. Analytical assessment of $5.05 \mathrm{kWp}$ grid tied photovoltaic plant performance on the system level in a composite climate of western India. Energy 2016, 111, 47-51. [CrossRef]

54. Mondol, J.D.; Yahanis, Y.; Smyth, M.; Norton, B. Long term performance analysis of a grid connected photovoltaic system in Northern Ireland. Energy Convers. Manag. 2006, 47, 2925-2947. [CrossRef] 
55. Rahman, M.; Hasanuzzaman, M.; Rahim, N. Effects of various parameters on PV-module power and efficiency. Energy Convers. Manag. 2015, 103, 348-358. [CrossRef]

56. Celik, B.; Karatepe, E.; Gokmen, N.; Silvestre, S. A virtual reality study of surrounding obstacles on BIPV systems for estimation of long-term performance of partially shaded PV arrays. Renew. Energy 2013, 60, 402-414. [CrossRef]

57. Rampinelli, G.; Krenzinger, A.; Romero, F. Mathematical models for efficiency of inverters used in grid connected photovoltaic systems. Renew. Sustain. Energy Rev. 2014, 34, 578-587. [CrossRef]

58. Stetz, T.; Marten, F.; Braun, M. Improved low voltage grid-integration of photovoltaic systems in Germany. IEEE Trans. Sustain. Energy 2013, 4, 534-542. [CrossRef]

59. Stetz, T.; Yan, W.; Braun, M. Voltage control in distribution systems with high level PV-penetration. In Proceedings of the 25th European PV Solar Energy Conference, Valencia, Spain, 6-10 September 2010.

60. Von Jouanne, A.; Banerjee, B. Assessment of voltage unbalance. IEEE Trans. Power Deliv. 2001, 16, 782-790. [CrossRef]

61. Wong, J.; Lim, Y.S.; Tang, J.H.; Morris, E. Grid-connected photovoltaic system in Malaysia: A review on voltage issues. Renew. Sustain. Energy Rev. 2014, 29, 535-545. [CrossRef]

62. Lopez, O.; Teodorescu, R.; Freijedo, F.; DovalGandoy, J. Leakage current evaluation of a singlephase transformerless PV inverter connected to the grid. In Proceedings of the Twenty Second Annual IEEE Applied Power Electronics Conference (APEC 2007), Anaheim, CA, USA, 25 February-1 March 2007.

63. Elkholy, A.; Fahmy, F.; El-Ela, A.; Nafeh, A.; Spea, S. Experimental evaluation of 8 kW grid-connected photovoltaic system in Egypt. J. Electr. Syst. Inf. Technol. 2016, 3, 217-229.

64. Cobben, S.; Kling, W.; Myrzik, J. The making and purpose of harmonic fingerprints. In Proceedings of the 19th International Conference on Electricity Distribution (CIRED), Vienna, Austria, 21-24 May 2007.

65. Balcells, J.; Dolezal, J.; Tlusty, J.; Valouch, V. Impacts of renewable sources on power quality in distribution systems. ICEREPQ 2004, 4, 5-31. [CrossRef]

66. Bouchakour, S.; Cherfa, F.; Chouder, A.; Abdeladim, K.; Kerkouche, K. Experimental study of grid-connected photovoltaic system at CDER, Algiers. In Proceedings of the 2nd International Seminar on New and Renewable Energies, Ghardaia, Algeria, 15-17 October 2012.

67. Drews, A.; Beyer, H.; Rindelhardt, U. Quality of performance assessment of PV plants based on irradiation maps. Solar Energy 2008, 82, 1067-1075. [CrossRef]

68. Altin, M.; Goksu, O.; Teodorescu, R.; Rodriguez, P.; Jensen, B.; Helle, L. Overview of Recent Grid Codes for Wind Power Integration. In Proceedings of the 12th International Conference on Optimization of Electrical and Electronic Equipment, Brasov, Romania, 20-22 May 2010. 